\title{
An Interpretation of the Novel The Wedding of Zein in the Specific of Allegorical Interpretation as Literary Text Analysis Method
}

\section{Edebi Metin Çözümleme Yöntemi Olarak Alegorik Yorumlama Özelinde Zeyn'in Düğünü Romanının Bir Yorumu}

\author{
İbrahim GÜNAYDIN ${ }^{1}$ (1)
}

'Mimar Sinan University, Faculty of Literature, Philosophy Department, İstanbul, Turkey

\section{ORCID: I.G. 0000-0002-2794-594X}

Corresponding author:

Ibrahim GÜNAYDIN (Dr.),

Mimar Sinan University, Faculty of Literature,

Philosophy Department, İstanbul, Turkey

E-posta: ibrahimgunaydin1@gmail.com

Submitted: 08.05 .2021

Revision Requested: 03.06 .2021

Last Revision Received: 30.07.2021

Accepted: 30.07 .202

Citation: Gunaydin, Ibrahim. " An Interpretation of the Novel The Wedding of Zein in the Specific of Allegorical Interpretation as Literary Text

Analysis Method". Şarkiyat Mecmuası - Journal of Oriental Studies 39 (2021), 67-81.

https://doi.org/10.26650/jos.934984

\begin{abstract}
This article presents an analysis method for literary texts, basing on the authentic meaning of allegory. This method reveals itself as a text-centered critical analysis method. In this article, firstly, a brief etymological investigation of allegory was made. Then, some data determined as a result of the investigation were evaluated. These evaluations were aimed to form a basis for the methodological side of the article. On this basis, we attempt to infer the character of allegorical interpretation. The indicator of the word uttered is not always aimed. What is said may differ from what was aimed. This situation is frequently encountered in the arts of speech. Literary texts that consist of fiction can also contain this situation. Allegorical interpretation arises from such a possibility and builds itself on this possibility. Allegorical interpretation centering a literary text goes from the thing told to the thing aimed. There are signs in the telling. These signs actually relate to what is aimed. The allegorist as an allegorical interpreter tries to catch the meaning by making a critical analysis of these signs. Thanks to these signs, the aim is revealed. Therefore, this method perceives the narrartive of a literary text with this characteristic as a tool. In other words, according to the method, what is told in a literary text is actually a bridge for what is aimed to be told. This article practically realizes this method in the novel The Wedding of Zein by the Sudanese writer Tayyib Salih.
\end{abstract}

Keywords: Literary Text Analysis, Allegory, Allegorical Narrative, Allegorical Interpretation, The Wedding of Zein

\section{öz}

Bu çalışma, alegori sözcüğünün otantik anlamından hareketle edebi metinlere dair bir çözümleme yöntemi sunmaktadır. Bu çözümleme yöntemi, metin merkezli eleştirel bir çözümleme yöntemi olarak kendisini ortaya koymaktadır. Bu yöntemsel çalışmada ilk olarak alegori sözcüğünün kısa etimolojik bir incelemesi yapılmıştır. Böylelikle inceleme sonucu tespit edilen birtakım veriler değerlendirilerek çalışmanın yöntemsel tarafına dair bir zemin oluşturulmak istenmiştir. Bu zeminle beraber metin merkezli eleştirel bir çözümleme yöntemi olarak alegorik yorumlamanın karakteri çıkartılmaya çalışılmıştır. Anlatıcı 
tarafından dile getirilen bir ifadenin göstergesi her zaman hedeflenmeyebilir. Diğer bir ifadeyle dile getirilen, aslında amaçlanandan farklı olabilir. Bu duruma, konuşma sanatlarında sıklıkla karşılaşıır. Bir kurgudan oluşan edebi metinlerde de bu durum söz konusu olabilir. İşte alegorik yorumlama böylesi bir olasılıktan doğar ve kendini bu olasılık üzerine inşa eder. Edebi metinleri merkeze alarak eleştirel bir çözümleme yoluna giden alegorik yorumlama, ilgili edebi metinde dile getirilen ifadeden yola çıkarak amaçlanan şeye doğru giden bir yöntemdir. Nitekim metinde dile gelen ifadelerde birtakım işaretler vardır. Bu işaretler metin düzleminde gerçekte amaçlanan şeyle alakalı işaretlerdir. Bu işaretler sayesinde gerçekte amaçlanan şey ortaya çıkarılır. Dolayısıyla bu çözümleme yöntemi, bu özelliğe sahip bir edebi metnin anlatımını bir araç olarak algılar. Diğer bir deyişle, yönteme göre bu tür edebi metinlerde anlatılanlar aslında anlatılması gerekenler için bir köprüdür. Bu çalışma bu ilgili yöntemi Sudanlı yazar Tayyib Salih'in Zeyn'in Düğünü adlı romanı özelinde pratik olarak gerçekleştirmektedir.

Anahtar kelimeler: Edebi Metin Çözümlemesi, Alegori, Alegorik Anlatı, Alegorik Yorumlama, Zeyn'in Düğünü 


\section{Introduction and the Methodology Presented in the Article}

Allegory is a frequently used concept in the field of literature. It usually refers to the nature of a literary text. This concept is especially compared to other concepts used in the field of literature such as metaphor and symbol. Oftentimes these concepts are confused with each other. Therefore, they are intricately intertwined. However, the character of the allegory differs from these. This article focuses on the authentic meaning of allegory, leaving aside technical definitions and similarities with other concepts.

The aim of the article is to present a method of critical analysis on literary texts. The method intends to analyze literary texts based on allegorical narrative. Hence, religious texts are not covered by this method. ${ }^{1}$ Moreover, every literary text is not the subject of this method. The primary search for a literary text within the scope of this method is that its narrative has an implicit expression. What determines that a literary text contains an implicit expression is the literary text. As a matter of fact, the text reveals itself with its content as an existence that explains itself in itself. This content is the nature of the literary text. The thing manifests itself in itself. Hence, it is the literary text that reveals the allegorical value. Value exists in existence. It is not given to existence. Besides, an allegorist as an allegorical interpreter, can determine the implicit expression in a literary text. In this determination, the allegorical value of the literary text is made further visible. As something manifests itself in itself, something else can also manifest that thing. The allegorist reveals that the literary text has an implicit expression by explaining the concrete, sensible and real elements in the text. The allegorical value of the literary text is mainly derived from the text or through the allegorist.

At the same time, the author who built the text is also active in this determination. The person who brings something to existence brings the thing to existence for a value. This person is determining a value. This value is attached to it. The author points to that value in that thing. Thus, it is possible to talk about three different ways to determine whether a literary text has an implicit expression or not: literary text, allegorist and author.

The Alegorist discloses an implicit expression with a text-centered critical analysis. The disclosure of implicit expression is a process. This process is linked to the relation that the allegorist has established with the literary text. The nature of this relation is intellectually fed from the concrete, sensible and real elements in the text. Thus, the allegory in the literary text becomes visible by it.

1 There is no mention of an esoteric interpretation here. It is known that the activity of allegorical interpretation of divine texts is mostly esoteric. Especially esoteric interpretations of the Bible and the Torah are evaluated under the title of allegorical interpretation. However, when this issue is examined it will be seen that the allegorical interpretation used for Bible stories or Torah passages is methodologically different from the allegorical interpretation put forward here. They are similar names with different references. Therefore, in this article, an esoteric interpretation is avoided. For this reason, this study does not mention such an interpretation method. On the other hand, it should be underlined that the ontological level of divine texts is different from the ontological level of literary texts. While the source of divine texts is God, literary texts are human products. The method put forward in this study was created by considering the ontological structure of literary texts. Therefore, religious texts do not fall within the scope of this method. 
Expressions in the literary text are sometimes clear; sometimes it is not. Clear expressions tells directly what is being told. Thanks to these expressions, what is told is understood without the necessity of interpretation. Interpretation in this article is a kind of subjective explanation put forward to eliminate the obscurity in the text. Interpretation is also an opinion due to the subjective side. There is no need for interpretation in clear expressions in the text. In this case, the interpretation as something that differs from person to person and reflects the individual thoughts of people is not included in the clear expressions. Literary texts based on clear expression as is known lean on realism. Indeed realism as a literary movement, which can be considered as the application of positivism to literature, demands that what is seen is given as it is. Hence, it does not include implicit expression. Literary texts shaped through this literary movement considers to give directly what exists. Literary texts based on this trend are like a mirror against life. This mirror is used to reflect the existence as it is. Therefore, such texts tend to articulate what exists as it is. The meaning in such texts is not veiled.

The implicit expressions tell indirectly what is being told in the text. Unlike texts made with clear expressions what is being told in such texts is not given directly. Such literary texts want to explain what they want to tell with some expressions attributing to that thing aimed there. In literary texts created with implicit expressions what is actually meant to be told is absent on the visible face of the text. It is veiled. This veiled thing comes to light through connotation. The author places some symbols that allow connotation in the text for that shows what he actually aims to tell. For this, a symbolization is used by using the power of imagination in such texts. This symbolization is also a subjective fiction by the author. A narrative with these features implicit expressions, veiled meaning, symbols, connotations, symbolization, fiction, subjectivity is called allegorical narrative in this article. Literary texts shaped by allegorical narrative can be named as allegorical literary texts. The person who slants to the allegorical literary texts and brings out the meaning here is the allegorist.

For that allegorical literary texts are not easy to understand, it needs to be analyzed. This analysis should be of a critical nature. Critical involved in analysis is anatomizing and sifting. A critical analysis performed in this way in a literary text provides a strong interpretation. Therefore, the meaning of allegorical literary narratives is revealed through an analysis of it. This critical analysis is called allegorical interpretation in this article. The things that are in allegorical narrative and point to things aimed are determined and evaluated by alegorsit. This process started by the allegorist shows the process of producing meaning. The meaning that emerges in this process is a meaning of the literary text. It is a meaning from different meanings of the text because this method argues that every allegorist tries to seek a meaning and that all allegorical literary texts are suitable for it. Therefore the meaning of the literary text found by the allegorist is also an interpretation of the text. Therefore, this method avoids determining the real meaning of allegorical literary texts. In such texts, there are meanings appropriate to the context rather than the real meaning. The meaning put forward by an allegorist may be more appropriate than the meaning put forward by another allegorist. 
If we characterize this situation in another way, what is happening here is perspectivism. The interpretation that emerges from the relation established by the allegorist with the literary text within the logical criteria is not a final interpretation. There is no certainty here, contrarily there are some perspectives. Therefore, there are strong and weak ones among the interpretations. This depends on whether the interpretation is methodical within logical criteria. The prerequisite for allegorical interpretation is the formal analysis of the relevant literary work. This means that the allegorical interpretation process begins with formal analysis. The purpose of formal analysis is to focus on what the literary text says. The events, characters, place and time in the literary text are determined. The fictional structure, expression language and style are revealed. Thus, it will provide a suitable environment for allegorical interpretation.

\section{Allegory, Allegorical Narrative and Allegorical Interpretation}

The word allegory is a combination of the Greek words allos ( $\alpha \lambda \lambda \mathrm{o} \varsigma)$ and agoreuein

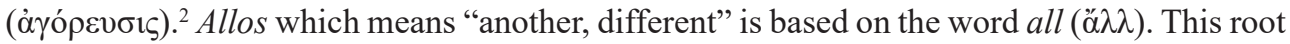
word means "beyond, on the other side of, on the further side of, outside". ${ }^{3}$ The Word agoreuein means "to speak, to tell". ${ }^{4}$ The root of it is the word ag which means "to move", "to lead". 5

As a result it can be said that certain meanings such as "to tell" and "to be beyond" are dominant in the linguistic representation of allegory. These meanings reveal that allegory is not an ordinary narrative. It is a narrative beyond the ordinary narrative. It is to go beyond the boundaries of ordinary narrative and to tell something in another field. This narrative is called an allegory. Hence, an ordinary narrative cannot be allegory. Therefore, allegory is defined as "veiled language". ${ }^{6}$ Veiled language means that the narrative is veiled. Therefore, in such a narrative, it will be seen that the meaning is also veiled. The narrator, as the person using the veiled narrative, does not explain something clearly while describing it. In other words, he does not make a direct narrative. Instead, he prefers indirect/implicit expression. He tells what he aims to tell in this way. Thus, the narrator puts a veil over what he aimed. In this

2 Jon Whitman, Allegory, Cambridge: Harward University Press, 1987, p. 263; Biblissima, á $\lambda \lambda \eta \gamma o \rho i \alpha$, Accessed January 17, 2021. https://outils.biblissima.fr/en/eulexis-web/index.php; Etymonline, allegory, Accessed January 25, 2021, from https://www.etymonline.com/search?q=allegory. www.biblissima.fr. This web address provides access to the following etymological dictionaries: Robert Scott (1867-1939) ve Henry George Liddell (18111898) A Greek-English Lexicon (1940), Wilhelm Pape (1807-1854) Handwörterbuch der griechischen Sprache (1880), Anatole Bailly (1833-1911), Bailly (2020). www.etymonline.com This web address also provides access to the following etymological dictionaries.: Ernest Weekley (1865-1954) An Etymological Dictionary of Modern English, Ernest David Klein (1899-1983) A Comprehensive Etymological Dictionary of the English Language, Oxford Üniversitesi Oxford English Dictionary, Robert K. Barnhart (1933-2007) Barnhart Dictionary of Etymology, Ferdinand Holthausen Etymologisches Wörterbuch der Englischen Sprache, Barbara Ann Kipfer ve Robert L. Chapman (1920-2002) Dictionary of American Slang.

3 Henry George Liddell \& Robert Scott, R. (1940). A Greek-English Lexicon, London: Oxford University Press, 1940, p. 67-68.

4 Ibid., p. 13-14.

5 Eric Partridge, Origins A Short Etymological Dictionary Of Modern English, e-Library: Taylor \& Francis, 2006, p. 68 .

$6 \quad$ Liddel \& Scott, A Greek-English Lexicon, p. 69. 
case, everything the narrator tells becomes the veil of what he actually aims to tell. Allegory necessitates the creation of a veiled language because of the essence that lies in its authentic meaning. This veiled narrative is called the allegorical narrative.

The narrator using a veiled narrative suspends the image. This image is an image of what he aims to tell. What is meant by the image here is appearance. With this suspension, the narrator hides what he is aiming for by leaning towards another appearance. It goes from an unmeant appearance to an image aimed. Therefore allegory which is a veiled narrative also means telling under another appearance. This also refers to a narrative under another image. Because of this feature of allegory, it is defined as follows: "Allegory is a description of one thing under the image of another". 7 The word "descriptive" in the definition is important. Indeed, allegorical narrative actually emerges with a descriptive intention. Because of that allegory is a description of what is not told but aimed. Therefore, the descriptive nature of allegory reveals that it is a model of explanation.

Derrida points to this veiled side of allegory while analyzing Paul de Man's Allegories of Reading. ${ }^{8}$ Allegory refers to something else in the sum of the words that make up it. Allegory always says something different than what it gives. Hence, the appearances of the allegorical narrative can be deceiving. However, what is visible as appearances points to the invisible with its deceptive identity, and what is visible is also important for this reason all the time.

What is expressed in the veiled narrative actually refers to one thing. In other words, whatever is told in the narrative field signifies what is untold but aimed. Therefore, there are actually two fields in allegorical narrative:

1. Visible field,

2. Invisible field.

There are explanations and descriptions in the visible field. All of these exists for the invisible field. Because the thing aimed is in the invisible field. The visible field is the field of image. Thanks to the field of image, the invisible field is reached. The visible field is like a bridge. Without this bridge it is not possible to reach the invisible field. As pointed out above thanks to some concrete sensible and real elements in the visible field, reach becomes possible. The elements here are open to everyone. In other words anyone can understand them. They are indicators that sign the invisible field. The indicator is signed as a linguistic term. It should be noted that what is signified in these signs, is not fixed. This means that it may differ from person to person. Indeed, the signifier in these signs is something that can be understood. The signified is revealed by being exposed to an intellectual action. Intellectual action is a process. This is also the process of producing meaning. Allegorical interpretation emerges in this context. Determining and critically analyzing these elements in the visible field reveals the interpretation seen as one of the meanings of the text.

7 Etymonline, allegoria, Accessed January 18, 2021. https://www.etymonline.com/search?q=allegoria.

8 Jacques Derrida, Mémoires pour Paul de Man, Paris: Galilée, 1988, p. 34. 
Literary text is the visible field. Allegorical interpretation moves in this field. This field needs to be resolved methodically. It moves from this field to the invisible field. This invisible field cannot be fully penetrated. However, interpretations can be made regarding this field. As stated above this interpretation may be strong or weak. In order for the interpretation to be strong, the elements in the visible field should be analyzed meticulously. Each interpretation shows a meaning. The difference in this meaning depends on the position at which the interpreter stands. What a literary text tells directly reveals a single signified, while what it means will change according to the allegorist's perspective. Perspectivism in the process of producing meaning not an arbitrary relativism. Thus, the allegorical interpretation is a text-centered critical analysis method and the interpreter as an allegorist must carefully analyze the text in order to reach a strong meaning. Therefore, in this method, the meaning of the literary text is what the interpreter understands.

In order to better understand the authentic meaning of the allegory, it is useful to consider Plato's cave allegory. Plato tells something to Glaucon through Socrates in the Seventh Book in Republic. What Socrates is telling is a thing designed. In this design, there are events and situations. This design is essentially a model of explanation and description. Socrates wants to point to a thing through this narrative he designed. This is exactly the description of one thing under the image of another. In other words, Socrates tells something. However, he aims for another with what he is telling. He points to what is not visible through what is visible. In this context, allegory is a representation. The narrator has set up a representation by establishing subjective relations between the visible and the invisible. Therefore, allegory is a fictional representation. The distinctive features in this fictional representation reflect and symbolize the invisible. As an act of representation and/or symbolization, allegory essentially reflects a thought. The narrator directs a mirror to his own thoughts through allegory and tries to reflect what he thinks to the outside world.

\section{An Interpretation of The Wedding of Zein Through Allegorical Interpretation}

Before entering the allegorical interpretation process of the novel The Wedding of Zein, a brief information will be given about the novel and its author. Then, some elements in the novel, setting the ground for allegorical interpretation will be mentioned. After these are done, the allegorical interpretation of the novel will begin.

The Wedding of Zein was published in Arabic in 1962 and translated into English in 1968 by Denys Johnson-Davies. Within the realm of Arab literature, the book is considered a classic. The novel which many research articles, theses and examinations have been made about has been translated into many languages including English, German, French, Spanish, Persian, Turkish, and Polish. In addition in 1976 this novel was adapted with the same name to the 
film directed by Khalid Al Siddiq. ${ }^{9}$ Salih is one of the Arab world's top authors. He was born in 1929 in the northern Sudanese village of Marawi to a family of Arabian origin. He was educated first in Islamic schools like other children of the village. After studying at British educational institutions such secondary school and high school in his region he graduated from University of Khartoum with a Bachelor of Science. After working as a teacher for a while in Sudan he went to London for education in the University of London in the United Kingdom. He worked for the British Broadcasting Corporation's (BBC) Arabic Service for more than 20 years and In 1974 he resigned from there. Later he became director general of the Ministry of Information in Doha, Qatar. The last ten years of his working career, he spent at UNESCO. ${ }^{10}$ Salih who started writing in London in the 1950s published stories such as Douma Wad Hamid and A Handful of Dates. Starting from the 1960s he has written novels exceeding national borders such as Season of Migration to North (1966), Bandarshah (1971), Maryud (1978). ${ }^{11}$

The main character of this novel The Wedding of Zein is Zeyn who is at the center of the novel. The main event on which the novel is based is the wedding of Zein. Zein is a character who stands out with his extreme ugliness and unimaginable different behaviors. Clear expressions about the historical time of the events in the novel are not mentioned in the text of the novel but the time in which the novel takes place can be determined by analyzing the historical elements in the novel. The time period extracted through the processing of historical elements is from the 1950 s to the $1960 \mathrm{~s}$. The events of the novel most likely take place in this date range. There are clear expressions in the novel about the setting of the novel. This setting is in a village on the Nile in the Northern State of Sudan. Consequently, the plot of the novel is the wedding of someone named Zeyn who has a freakish character in all aspects, in a village on the Nile in the Northern State of Sudan in the 1950s, with Ni'ma who is one of the most beautiful girls in the village. Another important character of the novel is a dervish named Haneen. As can be seen below the relationships between this dervish and Zein carry a part of the message the novel wants to convey. Mahjoub, Imam, Headmaster are among the other important characters.

In this article, the allegorical interpretation of the novel will be shaped over a few elements in the novel. These elements can be summarized as follows: the setting of the novel, the main character Zein's relations with Haneen and Ni'ma, the attitudes of characters such as Mahjoub, Imam and Headmaster.

9 Wail Seddiq Hassan, Tayeb Salih: Ideology and the Craft of Fiction. Syracuse: Syracuse University Press, 2003, p. $\mathrm{x}$.

10 John Charles Hawley, Encyclopedia of Postcolonial Studies, London: Greenwood Press, 2001, p. 397; Britannica, T. Editors of Encyclopaedia (2021, February 14), Al-Tayyib Șālih. Accessed February 30, 2021 Encyclopedia Britannica. https://www.britannica.com/biography/al-Tayyib-Salih.

11 Constance E. G. Berkley, "El Tayeb Salih, The Wedding of Zein", Journal of Arabic Literature, 11, (1980), p. 105-114. Accessed March 30, 2021. http://www.jstor.org/stable/4183036; Hassan, Tayeb Salih: Ideology and the Craft of Fiction, p. $\mathrm{x}-\mathrm{x} 1$. 
Small, large, with or without a garden; many different styles of houses, squares, bazaars, commercial shops in the market, cultivated lands, highways connecting cities, mosques, oases, health, social and administrative institutions, groups of different lineages, people with different ideologies, conflicting classes or compromising classes, children, young, old, different age groups, cemetery, entertainment activities, weddings, funerals, births, deaths... A village is depicted with each of these in the novel.

Some expressions in the novel on these attributes are as follows:

"Zein himself was at the well in the centre of the village, filling the women's pitchers for them and indulging in his usual antics". ${ }^{12}$ "Badawi was well-off, possibly the richest man in the village". "No sooner had the inhabitants of the village accustomed their ears to that than to their amazement they saw Seif ad-Din repairing the mosque for the Friday prayers". ${ }^{4}$ "The Headmaster did not use the expression 'chap' or 'man' like the other villagers, but would begin his sentences by using the phrase "my dear fellow". ${ }^{15}$ With schools being set up in the village, also a hospital and an agricultural project, it was they who were the contractors and overseers; they who made up the committees responsible for everything. ${ }^{16}$

There is no mention of the name of the village. If this village had been given a name, the village could be limited at the imaginary level. As a matter of fact, naming something is to make it distinct among similar ones and to put a limit on it. The author avoided such a limitation leaving it unlimited at the imaginary level. This is important in stimulating the reader's imagination. Considering the above attributes of this village, every residential place in the world is similar to this place. These attributes of the village are present in every residential area. Because, wherever there are people, there is nothing more natural than these things. All the attributes of the village depend on the human factor. Everything, from the educational institution to the social structure of the village, from its bazaar to its cultivated land, is shaped by people. As a result, although this village geographically shows a residential area in the Northern State of Sudan, it actually symbolizes a place where all humanity has lived, it is the world. The world, with its spatial features, shows every place in which human life takes place. It is human life that makes the world world.

This interpretation of the village in the novel is allegorical. As a matter of fact, this interpretation was arrived at by going from the visible field to the invisible field and from expressions in the novel to what is actually aimed. On the other hand, what allows such an allegorical interpretation made above are the signs in the narrative of the novel, as can be seen above. These signs were able to establish relationships between the two fields. The visible

12 Tayeb Salih, The Wedding of Zein And Other Stories. (D. Johnson-Davies, Trans.). New York: New York Review Books, 2011, p. 48.

13 Ibid., p. 77

14 Ibid., p. 83.

15 Ibid., p. 88.

16 Ibid. p. 98. 
field in this novel is a certain geographically bordered village, while the invisible field is everywhere human life occurs.

On the other hand, the village which is a symbolic element in which human life continues and flows, should also be evaluated on its structures. On the one hand the village has a bazaar, a shop, "madrasah", on the other hand it has a mosque and a religious education institution "kuttab". Each building in sight has its own workplace. However, when a commercial shop and a mosque are considered thoroughly it will be seen that this situation actually refers to the material and spiritual. Each of these structures is a symbolic element when evaluated on either of these two sides. "Madrasah" as a place where modern education is given in the village symbolizes secularity, while the "kuttab", a religious place of education, represents spirituality. The mosque as a place of worship and the tobacco shop inside the bazaar have the same functionality.

The allegorical aspect of the novel refers to the existence of each of these structures through human factors. Humans are the reason for the existence of all structures in the village. In this context, humans represent the material in one aspect and the spiritual in the other. Therefore, people consider these two aspects while constructing the village. People who have these two aspects do this in order to nourish both sides by not making any discrimination. In other words, a person cannot ignore and marginalize one of them while accommodating the other.

People with very different characters live in this world. Some of these people are like Zein, others are like Haneen. Naturally, not all people are like these two characters. However, the novel tries to create a thought through these two characters. Namely the novel tries to show some things with these. These two characters are actually symbols that refer to other things. As stated above, the village was not actually just a village. Likewise, these two characters are not just two characters. They will show what is beyond the visible. As mentioned above, the authentic meaning of allegory also shows beyond the ordinary. In the novel, Zein usually eats, drinks, loafs, likes to talk, wanders, walks about, has fun, dances, sings, capers, laughs, cachinnates, flirts, loves, falls in love.

Some expressions in the novel on these attributes are as follows:

The children gathered round him and began chanting, 'Zein's getting married. -Zein's getting married, 'while he hurled stones at them, tugged at a girl's dress, prodded a woman in her middle, or pinched another's thigh; children laughed, the women shrieked and laughed, and above all this laughter could be heard the laugh that had become part of the village ever since Zein was born. ${ }^{17}$ "On the way from the kitchen to the diwan Zein dawdled along, eating the choicest bits from the dish he was carrying, so that on arrival it was all but empty". "The story of Zein's love for Alawiyya the daughter of Mahjoub is the latest of his romances". ${ }^{19}$

17 Ibid., p. 48.

18 Ibid., p. 50.

19 Ibid., p. 53. 
-Hear ye, people of the wedding, men of the dance, Zein has come to you. And with a leap Zein would land like Destiny herself in the dance circle. Suddenly the place would quicken into life, for Zein would have imbued it with new vigour. ${ }^{20}$

He lives to the fullest all things that are in the material aspect of life. With these attributes, Zein represents the secular aspect of life in the world. Haneen prays, eats less, drinks less, talks less, does not like socializing with people, lives in seclusion, lives a life of asceticism. ${ }^{21} \mathrm{With}$ these attributes, Haneen is in a different position from Zein. Haneen means "longing" in the dictionary. This longing is a craving for spirituality in a world where the material aspect is overwhelming. Hence, Haneen also represents the spirituality of this world. Zein means "beautiful" in the dictionary. Zein's aforementioned attributes also point to the beauty in the world.

These lifestyles in two different dimensions of life can understand and nurture each other and live with each other very well. The novel establishes a relationship between Zein and Haneen in order to show this situation. With this relationship, two aspects that seem apparently opposite to each other are intertwined and lived together without any negative situation. This situation gives the following message: The life of the world exists in both secular and spiritual aspects. The village people represent all the people who live in this world and have different ideas. While some of these people shape their lives with the material side of the world, some of them live only in the spiritual aspect. Those who live these two dimensions of life are few. As a matter of fact, there are few people like Zein or Haneen in the village.

Everyone should benefit from these two aspects. Despite all his material aspects, when Zein sees Haneen he leaves this lifestyle aside and takes care of him. In spite of all his spirituality, when Haneen sees Zein, he spends a long time with him and lives the material life. One of these two aspects of life may be more dominant in your life. As seen in Zein, you can experience the material side of life to its fullest. As you can see in Haneen, you take the material side of life out of your life at the maximum level and you live the spirituality with all of yourself. However, if only one of these two aspects dominates your life, then you are a lost person. Thus, worship, abstinence from all pleasures and asceticism does not indicate life. At the same time to taste all the pleasures of the material side of life is also not real life. Life in this world exists in both material and spiritual aspects. It is wrong to prefer one and to take the other out of life. Life is a whole in these two aspects. The human is in life with these two aspects. In this context, Zein and Haneen, together with their symbolic values, refers to these two situations of human being. The novel opposes the breakdown and division of these two aspects in life and human being and doesn't allow this.

Ni'ma who is another character in the novel, carries two aspects. She among the girls of the village is charming, stately and beautiful. She is a girl that everyone admires with her beauty. ${ }^{22}$ Thus, Ni'ma represents the material aspect of life with these features. She also symbolizes

20 Ibid., p. 68.

21 Tayeb Salih, Urs Al-Zein, Beirut: Dar Al-Ceal, 1997, p. 22; Salih, Urs Al-Zein, (2011), p. 58.

22 Salih, Urs Al-Zein, (1997), p. 32-33; Salih, Urs Al-Zein, (2011), p. 61-62. 
spirituality with her pure and disinterested faith. When Zeyn sees Ni'ma, he throws aside all his flirting, all his pranks, all his idleness, and shows his respect for the spiritual from a very high veil.

Zein will marry Ni'ma who has these two aspects. It is important that these two aspects of life come together; however, this must be through consent, not using violence. Namely with violence, these two aspects cannot coexist. Ni'ma and Zein's consent to this marriage represents the peace between these two aspects. Izza who is Zein's first love and Haliema who is the other love are people who are lacking spirituality in spite of that they stand out with the material aspect. These two characters symbolize the person who is left unfinished by missing one of these aspects of life. As a matter of fact, Izza did not oppose her father's exploitation of Zeyn. Halieme despised Zein. Thus, they have shown that their spiritual aspects are lacking. However, Ni'ma who comes from a noble and wealthy family, never despised Zein. As in the novel, she ventured to confront her family by marrying Zein, who looks like a freak and belongs to the lower class.

Mahjoub represents someone who tries to solve everything with his mind, ${ }^{23}$ because he sees the material aspect of life, and who has doubts about believing in spirituality because he has not witnessed or experienced anything about the spiritual throughout his life. After the incident of Zein, Haneen and Seif ad-Din, Mahjoub's doubts about the spiritual dimension of life disappeared. Thus, it has expanded the range of interpretation of the events that take place in life.

The common point of the Imam and the headmaster is that they represent an institutional structure. Imam represents spirituality. The headmaster also represents the material. Such an idea can come to mind. However, this is not the case. ${ }^{24}$ In the novel, the imam is someone who does not respect people who represent the spiritual dimension of life like Haneen. The headmaster also denies this aspect of life; It prefers to explain all events, facts and situations by rationalizing. This is one of the common points of the imam and the headmaster; their refusal to accept spirituality. In this context, the novel points out that the institutional is in connection with the rational. Another common point is that their names are mentioned in the novel. They are characters without names. Their institutional aspects are at the forefront. With these features, they once again show that they are the representatives of institutionalism. On the other hand, they both oppose the marriage of Zein and Neame, which represents the intertwining of the spiritual and the material and also they don't like Haneen.

There are some signs in the novel about the beliefs of the village people. As understood from these signs, it is seen that this belief is Islam. However, why does the novel not give the name of this religion explicitly, even if somehow? In the answer to this question, it is possible to see once again that the novel attaches importance to allegorical narrative. As

23 Salih, Urs Al-Zein, (1997), p. 49-50; Salih, Urs Al-Zein, (2011), p. 84-85.

24 Salih, Urs Al-Zein, (1997), p. 73-77-33; Salih, Urs Al-Zein, (2011), p. 97-99. 
has been seen so far, the allegorical aspect in the novel strives to point to the universal. This situation aims at the universal, namely independent of people, institutions, frozen ideas that are paralyzing life. In other words, it tries to show what concerns all humanity. Therefore, a certain religion, followers, rituals and similar things are not important. The important thing is belief. This belief may be Islam, Christianity, Judaism or a similar religion. This village could be somewhere in Europe or Asia or North America. Between the lines of the novel, there would be signs showing this belief. In this context, Haneen could have been a monk, a church instead of a mosque, and a priest instead of an imam. Therefore, everything about Islam as a belief represents another belief.

It is possible to interpret many elements in the novel by these two aspects of life. These two aspects of life are presented to the reader by preferring implicit expression instead of direct expression. There are allegories in this implicit expression as veiled language or visible and invisible fields. Therefore, the narration of the novel is allegorical. There are many intertwined allegories in the novel. However, it should be noted that all intertwined allegories actually represent a single allegory. This allegory shows that life has two aspects and it is necessary to perceive it with these two aspects. As seen above, the village, buildings, Zein, Haneen, Niema, Izza, Haliema, Mahjoub, Imam, and headmaster are all an allegory in themselves. But ultimately, all of them are tools that serve the main allegory.

\section{Conclusion}

The allegory that authentically refers to the implicit narrative has two fields; visible and invisible. The field seen is the field of the text in which the narrative is made. The invisible field is the field that the narrative in the text wants to show. In other words, there are two things in allegory: the implied and the expressions of the narrative of the literary text. Allegorical interpretation based on the concept of allegory aiming at the analysis of literary texts moves from the visible to the invisible area. The thing implied in the allegorical narrative shows itself through the expressions of the narrative. What is meant to be expressed in literary text can be known through the expressions of the literary text. The first task of the method of allegorical interpretation is to focus on what the literary text tells directly. Therefore, the first step in allegorical interpretation is the formal analysis of the relevant literary text. The concrete elements obtained through this formal analysis provide both opportunity and space for allegorical interpretation. These elements in the visible field are in a connection with the invisible area. The allegorist, as the text analyzer, exposes this secret link.

After the first stage is passed, it is possible to move to the second stage. Allegorical interpretation offers a text-centered critical method in literary texts based on allegorical narrative, led by the allegorist. This method contains two important elements; text and allegorism. The allegorist's perspective solves the allegory of the text. This method, which is based on a kind of perspectivism, predicts that literary texts shaped over allegorical narrative can have 
many meanings. The interpretation put forward by the allegorist who turns to the literary text for the purpose of analysis is only one of the possible meanings of the relevant text. This approach, which strongly rejects rigid relativism, avoids haphazard attempts at interpretation and recommends a systematic and logical interpretation of the text.

This method of critical analysis text-centered which is named as allegorical interpretation practically realizes itself in the novel The Wedding of Zein by Sudanese writer Tayeb Salih. Places, persons, some relationships between people, some items, some situations of the novel were allegorically interpreted. Allegory seen in all pages of the novel is that life has two aspects, one is the material, the other is the spiritual aspect. These two aspects are the whole and inseparable. Choosing one over the other corrupts life. A single window shallows life. It makes people narrow-minded. It makes it conservative. Indeed, life also is a whole. These two aspects of life do not fight each other. Instead, they feed each other. They live in peace. People of these two aspects are unbroken, completed, undivided and whole people. People who have one of these also are broken, incomplete, divided and unwhole people.

Hakem Değerlendirmesi: Dış bağımsız.

Çıkar Çatışması: Yazar çıkar çatışması bildirmemiştir.

Finansal Destek: Yazar bu çalışma için finansal destek almadığını beyan etmiştir.

Peer-review: Externally peer-reviewed.

Conflict of Interest: The author has no conflict of interest to declare.

Grant Support: The author declared that this study has received no financial support.

\section{Kaynakça/References}

Abbas, A. 46-60, 1974. "Notes on Tayeb Salih: Season og Migration the The North and The Wedding of Zein”. Sudan Notes and Records, 55, 46-60. Accessed March 30, 2021. http://www.jstor.org/stable/42677954.

Berkley, C. E. G. “El Tayeb Salih, The Wedding of Zein”. Journal of Arabic Literature, 11, 105-114,1980. Accessed March 30, 2021. http://www.jstor.org/stable/4183036.

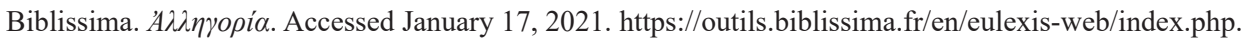

Britannica, T. Editors of Encyclopaedia (2021, February 14). Al-Tayyib Șāliḥ. Accessed February 30,2021 Encyclopedia Britannica, from https://www.britannica.com/biography/al-Tayyib-Salih.

Derrida, J. Mémoires pour Paul de Man. Paris: Galilée,1988.

Dwds. Allegorie. Accessed January 18, 2021, from https://www.dwds.de/wb/Allegorie.

Etymonline. Allegoria. Accessed January 18, 2021. https://www.etymonline.com/search?q=allegoria. *al. Accessed January 22, 2021, from https:/www.etymonline.com/word/*al-. Agora. Accessed January 24, 2021. https://www.etymonline.com/word/agora?ref=etymonline_ crossreference. Allegory. Accessed January 25, 2021. https:/www.etymonline.com/search?q=allegory.

Hassan, W. S. Tayeb Salih: Ideology and the Craft of Fiction. Syracuse: Syracuse University Press, 2003. Hawley, J. C. Encyclopedia of Postcolonial Studies. London: Greenwood Press, 2001. 
Liddell, H. G., Scott, R. A Greek-English Lexicon. London: Oxford University Press, 1940.

Man, P. de The Retoric of Temporality. Minnesota: University of Minnesota Press, 1983.

Partridge, E. Origins A Short Etymological Dictionary Of Modern English. e-Library: Taylor \& Francis, 2006.

Plato. The Republic of Plato. (Allon B. Trans.). New York: Basic Books, 1991.

Salih, T. Urs Al-Zein, Beirut: Dar Al-Ceal, 1997.

Salih, T. The Wedding of Zein And Other Stories. (D. Johnson-Davies, Trans.). New York: New York Review Books, 2011.

Whitman, J. Allegory. Cambridge: Harward University Press, 1987. 
